\title{
PERAN KOPERASI KARYAWAN UIKA (KIKA) DALAM MENSEJAHTERAKAN ANGGOTA (STUDI KASUS PADA KOPERASI KIKA UNIVERSITAS IBN KHALDUN BOGOR)
}

\author{
Ikbaludin \\ Program Studi Ekonomi Syariah, Fakultas Agama Islam, Universitas Ibn Khaldun Bogor Jl. \\ K.H. Sholeh Iskandar Km.2 Kedung Bada, Tanah Sareal, Bogor, Jawa Barat. \\ Ikbaludin48@gmail.com
}

\begin{abstract}
Abstrak : Tulisan ini ditujukan untuk mengetahui proses kegiatan koperasi karyawan UIKA dan perannya dalam mensejahterakan anggotanya. Metodenya menggunakan pendekatan metode kualitatif. Teknik pengumpulan data dilakukan dengan cara observasi, interview (wawancara) dan dokumentasi. Penentuan informan diambil secara purposive sampling. Hasilnya diketahui bahwa Koperasi Karyawan Universitas Ibn Khaldun Bogor mampu menunjukkan perannya sebagai alat perjuangan dan dapat mensejahterakan anggota koperasi UIKA.
\end{abstract}

\section{Kata Kunci: Peran, Kegiatan Usaha, Kesejahteraan, anggota.}

Abstract : The purpose op writing this essay is to find out the process of UIKA employee coopreative activities, and to know the role of UIKA cooperatives in improving the welfare of members. In this study, the authors used qualitative methods. While the technique of data collection is done by observation, interviews, and documentation. And sampling is done by purposive method. From the results of the study known that the Koperasi Karyawan UIKA (KIKA) cooprative was able to show its role as a tool of struggle and could prosper the members.

Keywords: Role, Business Activities, Welfare, Members.

\section{PENDAHULUAN}

\section{A. Latar Belakang Masalah}

Koperasi adalah bagian dari lembaga yang bergerak dalam bidang perekonomian. Berbicara tentang ekonomi, sepertinya pada bagian awal kita mempertanyakan apa yang sebenarnya menjadi tujuan ekonomi. Para ekonom kontemporer saat ini meliputi lima hal, pertama, penciptaan lapangan kerja/m enghilangkan pengangguran. kedua, distribusi pendapatan yang merata (adil). Ketiga, pencipaan efisiensi. Keempat, memantapkan stabilitas harga. Kelima, memacu pertumbuhan (economic goals menurut versi Wonnacot) (Mutis, 1992: 13).

Berdasarkan pengalaman, kegiatan saling membantu (gotong royong, solidaritas, dan perhitungan ekonomi) 
diantara individu dan usaha akan lebih berhasil mengatasi permasalahan baik sosial maupun ekonomi. Apalagi dalam menghadapi ekonomi pasar dimana persaingan pasar sangat ketat akan menyebabkan Usaha Mikro Kecil Menengah (UMKM) semakin tidak berdaya. Dalam ketidak berdayaan ekonomi seperti ini kekuatan-kekuatan ekonomi seperti usaha besar akan menguasai UMKM baik dalam pemasaran hasil produksi maupun dalam penyedian sarana-sarana produksi. Hal ini menyebabkan usaha-usaha kecil dan menengah harus bergabung dalam suatu wadah (koperasi) untuk menghadapi monopolis, meningkatkan kemampuan produksi dan memasarkan hasil produksinya. (Sartika dan Soedjono, 2002: 40).

Koperasi muncul karena adanya kesulitan ekonomi, kesenjangan pendapatan dan sebagainya (Mahmud, 1986: 109). Pendirian koperasi bertujuan untuk memperbaiki perekonomian dan meningkatkan kesejahteraan masyarakat. Salah satu program tersebut adalah koperasi (Susanti, 2015: 559).

Koperasi merupakan badan usaha yang beranggotakan orang-seorang atau badan hukum koperasi dengan melandaskan kegiatannya berdasarkan prinsip koperasi sekaligus sebagai gerakan ekonomi rakyat yang berasaskan kekeluargaan. Anggota koperasi wajib untuk saling bekerjasama dan saling tolong-menolong. Pada prinsipnya pengelolaan koperasi dilakukan atas kehendak dan keputusan anggota. Anggota memegang dan melaksanakan kekuasaan tertinggi dalam koperasi. Dalam pengelolaannya koperasi dilakukan secara demokratis, tidak otoriter, dimana kekuasaan tertinggi koperasi ada pada rapat anggota dan setiap anggota mempunyai hak suara yang sama dalam menentukan keputusan.

Dalam rangka pelaksanaan demokrasi ekonomi, koperasi harus dikembangkan dan ditingkatkan kemampuannya serta dibina dan dikelola secara efisien. Koperasi merupakan wadah perekonomian yang sesuai dan sangat penting dalam menumbuhkan dan mengembangkan potensi ekonomi rakyat serta dalam mewujudkan ekonomi yang bercirikan demokrasi, kebersamaan dan kekeluargaan guna memajukan kesejahteraan anggota pada khususnya dan masyarakat pada umumnya serta ikut membangun tatanan perekonomian nasional dalam rangka mewujudkan masyarakat yang maju, adil dan makmur berdasarkan pancasila Undang-Undang Dasar 1945 (Saebani, 2016: 3). 
Sesuai dengan latar belakang koperasi di atas, peranan koperasi sangat penting dalam usaha mensejahterakan anggotanya dan meningkatkan pemerataan pendapatan dan kemakmuran. Koperasi berperan untuk meningkatkan taraf hidup anggotanya, baik dari segi ekonomi maupun sosial (Sari, 2010: 2).

Koperasi Karyawan UIKA (KIKA) adalah salah satu lembaga yang menjadi alat gerakan ekonomi bagi masyarakat serta ikut membangun tatanan perekonomian nasional dengan mengemban misi meningkatkan kesejahteraan para anggota khususnya dan masyarakat pada umumnya. Menyadari pentingnya peranan koperasi dalam meningkatkan taraf hidup anggotanya serta mengantarkan anggota pada arah tingkat kehidupan yang lebih baik, maka penulis tertarik untuk meneliti permasalahan yang ada di Koperasi Karyawan Universitas Ibn Khaldun Bogor.

Berdasarkan dari paparan latar belakang masalah di atas, maka peneliti rumuskan masalah dalam penelitian ini adalah:

1. Bagaimana Proses Kegiatan Koperasi Karyawan Universitas Ibn Khaldun Bogor?

2. Bagaimana Peran Koperasi Karyawan Universitas Ibn Khaldun Bogor dalam mensejahterakan anggota Koperasi?

\section{B. Tinjauan Pustaka Pengertian Koperasi}

Menurut Undang-Undang No. 12 tahun 1967 tentang pokok-pokok perkoperasian pasal 3, koperasi Indonesia adalah organisasi ekonomi rakyat yang berwatak sosial, beranggotakan orangorang atau badan-badan hukum koperasi yang merupakan tata susunan ekonomi rakyat sebagai usaha bersama berdasarkan atas asas kekeluargaan (Sartika dan Soedjono, 2002: 56).

\section{Landasan Hukum Koperasi}

1. Landasan Idiil

2. Landasan Struktural dan Landasan Gerak

3. Landasan Mental (Kartasapoetra, 1993: 6-7).

Landasan-landasan tersebut di atas sangat penting untuk memperlancar jalannya koperasi dalam menyukseskan tercapainya cita-cita dan tujuan koperasi, untuk memperbaiki nasib dan meningkatkan kesejahteraan hidup para anggotanya.

Dalam Islam Syirkah bentuk koperasi dibolehkan. sebuah haditsh qudsi Rasulullah bersbda: 


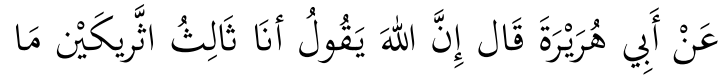

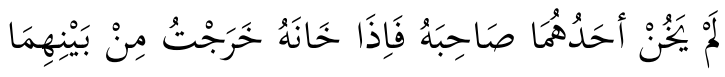

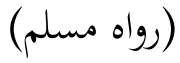

Artinya: "Dari Abu Hurairah, Rasulullah SAW bersabda “ Sesungguhnya Allah berfirman, Aku (Allah) adalah orang ketiga dalam perserikatan antara dua orang, selama salah seorang tidak mengkhiyanati yang lain, jika diantara mereka ada yang ber khiyanat maka Aku meninggalkan mereka berdua.“(HR. Muslim).

\section{Tujuan Koperasi}

Berdasarkan Undang-Undang Nomor 25 tahun 1992 tentang perkoprasian disebutkan bahwa koperasi bertujuan memajukan kesejahteraan anggota pada khususnya dan masyarakat pada umumnya serta ikut membangun tatanan perekonomian nasional dalam rangka mewujudkan masyarakat yang maju, adil dan makmur, berlandaskan pancasila dan Undang-Undang 1945 (Armala, 2016: 3).

\section{Keanggotaan koperasi}

Anggota koperasi adalah pemilik dan sekaligus penggunaan jasa koperasi. Keanggotaan koperasi dicatat dalam buku daftar anggota. Anggota koperasi adalah setiap warga Negara Indonesia yang mampu melakukan tindakan hukum atau koperasi yang memenuhi persyaratan sebagaimana ditetapkan dalam anggaran dasar (Susanti, 2015: 563).

Partisipasi anggota adalah hal yang sangat penting dalam pengembangan koperasi. Hal ini sejalan dengan hak anggota untuk memanfaatkan dan mendapat pelayanan dari koperasi. Anggota merupakan faktor penentu dalam kehidupan koperasi.

Sesuai dengan penjelasan di atas bahwa anggota koperasi sebagai pemilik sekaligus pengguna jasa koperasi berdasar pada kesamaan kepentingan ekonomi dalam lingkup usaha koperasi. Sebagai anggota memilki kewajiban yang harus dipenuhi, di patuhi dalam ketentuan yang berlaku serta dituntut berpartisipasi aktif untuk mengembangkan usaha dalam jalannya usaha koperasi.

\section{Kesejahteraan}

1. Pengertian

Menurut kamus bahasa Indonesia, kesejahteraan berasal dari kata sejahtera yang berarti aman, sentosa, makmur dan selamat atau dapat diartikan sebagai kata atau ungkapan yang menunjuk kepada keadaan yang baik, atau suatu kondisi dimana orangorang yang terlibat didalamnya berada dalam keadaan sehat, damai dan makmur.. 
Dari pengertian di atas dapat ditarik kesimpulan tentang kesejahteraan yaitu suatu keadaan atau kondisi yang terjamin keadaannya dan tercukupi segala kebutuhan baik fisik (makan, minum), maupun secara material (kepemilikan sandang dan papan). Kesejahteraan juga dapat diukur dari kemandirian masyarakat di dalam memenuhi segala kebutuhannya baik material maupun spiritual.

2. Tujuan

Tujuan kesejahteraan adalah untuk menjamin kebutuhan ekonomi manusia, standar kesehatan dan kondisi kehidupan yang layak, mendapatkan kesempatan yang sama dengan warga lainnya, peningkatan derajat harga diri setinggi mungkin, kebebasan berfikir melakukan kegiatan tanpa gangguan sesuai dengan hak asasi manusia (Walter A. Friedlander dalam Efendy, 2007: 118119).

3. Indikator Kesejahteraan

Ada beberapa indikator yang dapat dijadikan ukuran, antara lain adalah: Tingkat pendapatan keluarga, komposisi pengeluaran rumah tangga dengan membandingkan pengeluaran untuk pangan dengan non-pangan, tingkat pendidikan keluarga, tingkat kesehatan keluarga dan kondisi perumahan serta fasilitas yang dimiliki dalam rumah tangga.

Di dalam bukunya Irfan Syauqi Beik (2016: 29) "ekonomi pembangunan syariah" menjelaskan beberapa indikator kesejahteraan diantaranya sebagai berikut: pertama, kesejahteraan tidak akan mungkin diraih ketika kegiatan ekonomi tidak berjalan sama sekali. Inti dari kegiatan ekonomi terletak pada sektor rill, yaitu bagaimana memperkuat industri dan perdagangan. Sektor inilah yang menyerap angkatan kerja paling banyak. Indikator kedua adalah pemenuhan kebutuhan dasar dan sistem distribusi. Suatu masyarakat tidak mungkin disebut sejahtera apabila kebutuhan dasar mereka tidak terpenuhi. Indikator. Ketiga, kesejahteraan diukur oleh aspek keamanan dan ketertiban sosial. Tidak mungkin kesejahteraan dapat diraih melalui rasa takut dan tidak aman. Kesejahteraan sebagai tujuan utama pembangunan dapat diraih apabila tata kelola perekonomian yang baik dapat diwujudkan secara nyata.

\section{Jenis Penelitian}

Penelitian ini adalah penelitian ilmu sosial jika ditinjau dari bidang keilmuan dan jika ditinjau dari sifat permasalahannya penelitian ini merupakan 
penelitian deskriptif. Sedangkan jika ditinjau dari pemakaiannya, penelitian yang akan dilakukan pada penelitian ini adalah penelitian terapan (applied research). Adapun jika ditinjau dari pendekatannya penelitian ini merupakan penelitian kualitatif. 


\section{Populasi, Sample dan Teknik Sampling}

Populasi dalam penelitian ini adalah pengurus dan anggota Koperasi Karyawan Universitas Ibn Khaldun Bogor. Jumlah populasi pada Koperasi Karyawan UIKA (KIKA) berjumlah 280 anggota. Adapun dalam penelitian ini peneliti mengambil sample sebanyak 20 dari jumlah populasi.

\section{Teknik Sampling}

Teknik pengambilan sample dalam penelitian ini adalah purposive sampling. Sample proposive adalah teknik penentuan sampel dengan pertimbangan tertentu. Misalnya akan melakukan penelitian tentang kualitas makanan, maka sampel sumbr datanya adalah orang yang ahli makanan, atau penelitian tentang kondisi politik disuatu daerah, maka sampel sumber datanya orang yang ahli politik (Sugiyono, 2017: 114).

\section{Teknik Pengambilan Data}

Dalam penelitian ini, peneliti menggunakan beberapa teknik pengambilan data yaitu: "Observasi, wawancara (Interview), dan dokumentasi”.

\section{Teknik Analisis Data}

Metode analisis data yang digunakan oleh peneliti adalah metode analisis deskriptif yaitu metode yang digunakan dengan tujuan untuk menggambarkan fakta-fakta mengenai populasi secara sistematis dan metode ini akan menyajikan fakta-fakta hasil penilitian secara apa adanya (Kuntotjo, 2009: 4).

\section{Uji Validitas Data}

Uji validitas data menggunakan teknik triangulasi. Menurut sugiyono (2014) tringulasi adalah pengecekan data dari berbagai sumber dengan berbagai cara dan berbagai waktu. Peneliti menggunakan triangulasi waktu dengan cara melakukan wawancara dengan informan dalam waktu yang berbeda karena alasan kesibukan informan yang lain (Safitri, 2016: 39).

\section{Tahapan-Tahapan Analisis Data}

Dalam penelitian ini memiliki beberapa tahapan yaitu: pengumpulan data, reduksi data, dan penyajian data.

\section{PEMBAHASAN}

\section{A. Profil Koperasi Karyawan UIKA} (KIKA)

1. Sejarah Singkat Koperasi Karyawan UIKA (KIKA)

Awal mula berdirinya Koperasi Karyawan Universitas Ibn Khaldun Bogor sejak tahun 1983 atas keinginan pendiri Universitas yaitu K.H. Shaleh Iskandar. Beliau menginginginkan 
adanya unit bisnis yang bisa mengelola kebutuhan-kebutuhan yang ada di Universitas dan bisa memberikan dampak positif bagi anggota serta bisa menguatkan ekonomi umat. Seiring pergantian demi pergantian pengurus, sampai pada kepengurusan Bapak Widhi Ariyo Bimo beserta jajarannya yaitu sejak tahun 2015 atas dukungan dari Universitas dan semua pihak yang berkepentingan didalam pendirian koperasi ini, sehingga koperasi Karyawan Universitas Ibn Khaldun Bogor dapat berjalan sampai saat ini.

2. Sumber Dana Awal Pendirian Koperasi Karyawan UIKA (KIKA)

Sumber dana awal disediakan pihak Universitas senilai Rp. 100.000.000.00 dengan ditambah simpanan anggota, terdiri dari simpanan pokok dan simpanan wajib. Simpanan pokok yang pertama sebesar Rp.100.000.00, untuk simpanan pokok tersebut dilakukan hanya sekali untuk terdaftar sebagai anggota, sedangkan simpanan wajib yang merupakan sumber dana lainnya terdiri dari empat kategori: pertama Rp. 25.000, kedua Rp. 50.000, ketiga Rp. 75.000, dan ke empat paling tinggi Rp. 100.000, simpanan wajib ini dilakukan pada tiap bulan.
3. Jenis koperasi Karyawan Universitas Ibn Khaldun Bogor.

Koperasi Karyawan UIKA (KIKA) ialah koperasi serba usaha. Koperasi serba usaha adalah koperasi yang kegiatan usahanya di berbagai segi ekonomi, seperti bidang produksi, konsumsi, perkreditan, dan jasa. Koperasi juga memiliki beberapa fungsi yaitu sebagai yaitu: Perkreditan, Penyediaan dan penyaluran sarana produksi serta keperluan sehari-hari dan Pengelolaan serta pemasaran hasil (Susanti, 2015: $562)$.

4. Visi dan Misi Koperasi Karyawan UIKA (KIKA)

a. Visi

Menjadi koperasi yang amanah, profesional dan berkah.

b. Misi

1. Meningkatkan kesejahteraan anggota koperasi khususnya karyawan dan dosen.

2. Memberikan layanan yang terbaik bagi anggota baik pelayanan jasa maupun non jasa.

3. Menjadi alat gerakan ekonomi bagi masyarakat serta ikut membangun tatanan perekonomian nasional.

4. Tujuan 
Suatu organisasi tidak terlepas dari tujuan Tujuan Koperasi Karyawan UIKA (KIKA) adalah mensejahterakan anggota dengan motonya yaitu "Dari Anggota, Bersama Anggota dan Untuk Anggota”.

5. Prosedur menjadi anggota di koperasi karyawan UIKA

Prosedur untuk menjadi anggota di koperasi karyawan UIKA adalah: untuk karyawan yang tidak tetap, dilihat dulu kontrak kerjanya benar atau tidak bekerja di UIKA. Adapun yang statusnya karyawan atau dosen tetap wajib menjadi anggota di Koperasi Karyawan Universitas Ibn Khaldun Bogor, maka otomatis menjadi anggota, kemudian untuk teknisnya mengisi formulir ketersediaan untuk menjadi anggota, tanda tangan yang bersangkutan, dan memberikan simpanan wajibnya.

Simpanan wajib selama masih menjadi anggota koperasi tidak dapat di ambil, akan tetapi apabila mengundurkan diri ataupun ada hal yang lain seperti meninggal dunia, maka simpanan wajib akan dikembalikan $100 \%$ tanpa potongan berikut dengan bagi hasilnya apabila anggota tersebut sesuai dengan tingkat keaktifan dalam berkoperasi.
6. Kegiatan Usaha Koperasi Karyawan UIKA (KIKA)

Koperasi karyawan UIKA (KIKA) memiliki kegiatan usaha di bidang penjualan barang dan jasa serta menjalin kemitraan atau kerjasama yaitu sebagai berikut:

a. Penjualan barang

Penjualan barang merupakan salah satu unit kegiatan usaha Koperasi Karyawan Universitas Ibn Khaldun Bogor dengan mendirikan toko tempatnya di samping Fakultas Agama Islam. Dalam hal pendirian toko tersebut berisikan kegiatan usaha untuk pemenuhan kebutuhan sehari-hari. Seperti makanan, minuman (sembako), pulsa, buka tagihan listrik dan lainnya.

b. Jasa

Unit kegiatan usaha Koperasi Universitas Ibn Khaldun Bogor disamping penjualan barang, koperasi juga memiliki kegiatan usaha di bidang jasa. Seperti halnya penyedian barang elektronik, misalnya tv, hand phone, kulkas, laptop dan lain-lain yang bersipat elektronik.

Dalam unit kegiatan usaha dibidang jasa selain penyedian barang elektronik koperasi juga 
menyadiakan pelayanan serivis AC, menyediakan pelayanan pembuatan amamater, pembuatan surat undangan wisuda, ATK dan lain-lain.

c. Menjalin kemitraan atau kerjasama. Dalam kegiatan usahanya koperasi juga menjalin kemitraan atau kerjasama dengan berbagai kalangan untuk mewujudkan tujuan koperasi yaitu meningkatkan kesejahterakan anggota pada khususnya dan masyarakat pada umumnya kerjasama ini juga diharapkan dapat memberikan modal agar koperasi KIKA ini bisa berkembang, sehingga kesejahteraan khususnya anggota dapat meningkat. Pada umumnya koperasi KIKA ini bekerjasama dengan pedagang yang berada dilingkungan kampus dan lain-lain.

7. Perkembangan Koperasi Karyawan UIKA (KIKA)

Perkembangan koperasi Selama tiga tahun ini dikepemimpinan bapak Widhi Ariyo Bimo beserta jajarannya dengan dasar amanah berjalan dengan lancar dengan modal awal yang disediakan universitas dan dari simpanan anggota yang diputar atau di olah dengan sedemikian rupa dengan kegiatan usahanya sehingga menghasilkan keuntungan dan bisa menghasilkan manfaat untuk umat.

Adapun perkembangnnya diantaranya dapat membuat gedung kantin yang tempatnya saat ini di samping Fakultas Agama Islam (FAI), dan dari segi pelayanan-pelayan kebutuhan baik kebutuhan Universitas maupun anggota sedikit demi sedikit bisa dibenahi selama tiga tahun ini. Dan asset yang dimiliki Koperasi Karyawan Universitas Ibn Khaldun Bogor selama tiga tahun ini semakin meningkat dengan total tiga kali lipat dari modal awal.

Berdasarkan uraian di atas perkembangan Koperasi Karyawan Universitas Ibn Khaldun Bogor dari tahun ke tahun berjalan dengan baik dan lancar.

8. Peluang dan tangtangan yang dihadapi KIKA

a. Peluang

Seiring dengan padatnya aktivitas kampus dan banyaknya kebutuhan di lingkungan kampus, koperasi hadir sebagai sarana untuk memenuhi berbagai kebutuhan mahasiswa, dosen dan karyawan di civitas akademika UIKA sebagai pangsa pasarnya. Dalam pemenuhan kebutuhan tersebut, koperasi menyediakan seperti 
makanan, minuman, dan sarana perkualiahan seperti ATK dan lainlain saat ini koperasi memiliki peluang yang sangat potensial. Di samping itu, masih banyak peluang atau potensi yang harus dikembangkan, diberdayakan sehingga memberikan manfaat bagi anggota khususnya dan masyarakat pada umumnya.

b. Tantangan

Semua pekerjaan yang berada di lingkungan organisasi tentunya memiliki tantangan yang harus dihadapi, begitupula pada organisasi koperasi. Tantangan bisa menjadikan sebuah kemajuan dan perbaikan pada organisasi bila dihadapi dengan bijak dan cermat. Begitu pula sebaliknya jika tidak disikapi dengan baik maka tantangan tersebut akan berubah menjadi permasalahan yang besar bagi organisasi itu sendiri.

Pada dasarnya banyak tantangan yang dihadapi koperasi saat ini, seiring berkembangnya dunia usaha menyebabkan banyak bermunculan usaha-usaha yang baru yang menawarkan berbagai keunggulan dan hal ini berdampak pada terjadinya persaingan yag semakin kompetitif dalam merebut pangsa pasar. Hal ini juga menyebabkan semakin banyaknya pilihan konsumen dalam melakukan pembelian. Maka koperasi KIKA saat ini dihadapkan pada tantangan dalam hal meyakinkan anggota untuk berbelanja di koperasinya.

\section{B. Proses Kegiatan Koperasi}

\section{Karyawan Universitas Ibn Khaldun}

\section{Bogor}

Berdasarkan amanah yang diberikan pada pengurus beserta jajarannya untuk mengelola kebutuhan-kebutuhan yang ada di universitas dan bisa memberikan dampak positif bagi anggota serta bisa menguatkan ekonomi umat, maka dalam melaksanakan amanah tersebut, koperasi memiliki berbagai kegiatan. Mulai dari proses kegiatan penerimaan anggota, dalam hal tersebut tidak semua kalangan bisa menjadi anggota di koperasi KIKA. Yang bisa menjadi anggota hanya dosen dan karyawan Universitas Ibn Khaldun saja. Adapun untuk teknisnya mengisi formulir ketersediaan menjadi anggota. Setelah terdaftar menjadi anggota maka ada kewajiban yang harus dibayarkan pada koperasi sebagai simpanan, baik simpanan pokok maupun simpanan wajib. Simpanan pokok hanya 
dilakukan sekali pada saat pendaftaran

sebagai anggota, sedangkan simpanan wajib dilakukan tiap bulan sesuai kesepakatan dengan kriteria nominal yang telah ditetapkan. Apabila dana yang disimpan anggota semakin banyak, maka semakin besar pula perolehan Sisa Hasil Usaha (SHU) di akhir tahun.

\section{Peran KIKA Dalam Mensejah- terakan Anggota}

\begin{tabular}{lcr} 
& \multicolumn{3}{c}{ Sesungguhnya } & dalam \\
peranan koperasi dan & tugas \\
koperasi & adalah & untuk \\
meningkatkan & taraf & hidup \\
anggotanya, serta & koperasi \\
berperan guna & mencapai tujuan \\
akhir yaitu mencapai tingkat & man \\
kehidupan yang lebih baik (Sari,
\end{tabular}
2010: 2).

Untuk mencapai tujuan akhir tersebut Koperasi karyawan Universitas Ibn Khaldun Bogor berperan dalam beberapa hal yaitu sebagai berikut:

1. Memberikan pelayanan pembiayaan elektronik.

Contoh kasus: dari hasil wawancara dengan bapak Mulyadi. Beliau mengajukan pembiayaan hand phone dengan harga $1.500 .000 \mathrm{ke}$ koperasi dan beliau membayar sebesar Rp. 150.000.00 yang di potong dari gajinya tiap bulan, jadi tidak terasa dalam pembayaran, karena kalu membeli hand phone secara langsung kan susah tutur beliau. Bahkan bukan sekali atau dua kali, beliau pernah mengajukan pembiayaan elektronik sampai 3 kali.

2. Memberikan pinjaman uang dengan bagi hasil yang rendah. Untuk jangka waktu 1 tahun bagi hasilnya adalah $15 \%$

3. Setiap ramadhan ada peket yang dibagikan kepada semua anggota secara cuma-cuma tanpa terkecuali, baik yang aktif maupun tidak .

4. Anggota koperasi yang berbelanja di koperasi bisa membayar bulan depan (cash bon).

Peran koperasi di atas merupakan pelayananpelayanan yang di berikan koperasi untuk menanggulangi kebutuhan annggota koperasi.

Salah satu faktor yang terpenting dalam usaha koperasi adalah kemampuan dalam melayani, dengan kata lain pelayanan merupakan 
faktor yang terpenting dalam

usaha koperasi karena

berhubungan langsung dengan

kepuasan pengguna jasa.

5. Mengadakan pemeriksaan kesehatan gratis (kegiatan sosial).

Salah satu indikator kesejahteraan adalah kesehatan. Dalam upaya meningkatkan kehidupan anggota ke arah yang lebih baik, berdasarkan hasil wawancara dengan Lisa Marlina, koperasi pernah mengadakan kegiatan sosial berbentuk pemeriksahaan kesehatan. Seperti yang sudah dilakukan yaitu pemeriksaan kesehatan mata secara geratis.

6. Mencari peluang-peluang bisnis yang berpotensi menguntungkan koperasi bisa menguntungkan anggota koperasi khususnya dan masyarakat pada umumnya.

7. Bagi setiap anggota yang aktivitas belanjanya lebih banyak pada koperasi maka akan mendapatkan point, sehingga Sisa Hasil Usaha (SHU) yang didapatkan pun akan lebih tinggi.
Contoh: tuan A bertransaksi selama tahun berjalan sebesar Rp. 1.000.000. sedangkan tuan B bertransaksi hanya Rp. 100.000. Bagi hasil yang akan di bagikan pada anggota sebesar Rp. 10.000.000. total transaksi seluruh anggota adalah 100.000.000. Maka tuan A akan mendapatkan bagi hasilnya $1.000 .000 / 100.000 .000 \quad$ X 10 juta $=100.000$. Sedangkan tuan B mendapatkan bagi hasilnya $100.000 / 100.000 .000 \times 10$ juta $=10.000$.

\section{SIMPULAN}

Keberadaan Koperasi KIKA memberikan dampak positif bagi anggota serta bisa menguatkan ekonomi umat, maka dalam melaksanakan amanah tersebut, koperasi memiliki berbagai kegiatan. Dengan adanya kegiatankegiatan/keberlangsungan usaha dalam proses kegiatan koperasi, maka akan bisa memberi pelayanan-pelayanan yang bisa mengelola kebutuhan-kebutuhan yang dimiliki universitas serta memberikan dampak positif bagi anggota khususnya, umumnya pada umat sesuai dengan tujuan awal berdirinya koperasi KIKA.

Berdasarkan hasil wawancara mengenai peran koperasi dalam 
meningkatkan kesejahteraan anggota dapat dilihat dari tabel IV.9 yaitu sebagai berikut:

Tabel IV.9 berperan atau tidaknya koperasi untuk kesejahteraan anggota

\begin{tabular}{|c|c|c|}
\hline $\begin{array}{c}\text { Berperan } \\
\text { atau tidak }\end{array}$ & $\begin{array}{c}\text { Jumlah } \\
\text { Responden }\end{array}$ & Presentase \\
\hline Berperan & 20 & $100 \%$ \\
\hline $\begin{array}{c}\text { Belum } \\
\text { berperan }\end{array}$ & 0 & $0 \%$ \\
\hline $\begin{array}{c}\text { Tidak } \\
\text { berperan }\end{array}$ & 0 & $0 \%$ \\
\hline Total & 20 & $100 \%$ \\
\hline
\end{tabular}

Berdasarkan tabel di atas dapat diketahui berperan atau tidaknya koperasi KIKA untuk kesejahteraan anggota berdasarkan jawaban informan, responden yang menjawab berperan berjumlah 20 atau $100 \%$ dari jumlah keseluruhan responden. Maka dapat disimpulkan bahwa koperasi karyawan uika sangat berperan untuk kesejahteraan anggotanya.

\section{Saran -Saran}

1. Meningkatkan Sumberdaya Daya Manusia (SDM) sebagai antar jemput bola, dalam rangka pelayanan terhadap anggota. demi terpenuhinya kebutuhan anggota serta meningkatnya partisipasi anggota.
2. Mencari peluang-peluang bisnis diluar lingkungan universitas yang bisa memberikan keuntungan pada koperasi dan anggota.

3. Diharapkan anggota meningkatkan kesadarannya dalam berkoperasi untuk berpaetisipasi dalam melakukan transaksi pada koperasi sehingga SHU di akhir tahun nanti mengalami kenaikan yang tinggi. Selain itu ikut partisipasi dalam sumbangan saran, tenaga, fikiran sangat di harapkan dalam membantu pengembangan koperasi.

\section{DAFTAR PUSTAKA}

Saebani, Amad. (2016). Peran Koperasi Simpan Pinjam Dalam Memberdayakan Ekonomi Masyarakat, Skripsi Sarjana, Fakultas Ekonomi dan Bisnis Islam Institut Agama Islam Negeri Purwokerto.

Armala, Elysa Riska. (2016). Persepsi Mahasiswa Pendidikan Ekonomi Terhadap Koperasi Mahasiswa (KOPMA) Universitas Riau, Jurnal Online Mahasiswa, Vol. 3, No. 3.

Beik, Irfan Syauqi. (2016). Ekonomi Pembangunan Syariah. Jakarta: PT Raja Grapindo Perseda.

Kartasapoetra, Bambang, dan Setiady. (1993). Koperasi Indonesia. Jakarta: PT Rineka Cipta. 
Susanti, Maria Ira. (2015). Peran Koperasi Serba Usaha (KSU) "Mitra Maju" Dalam Meningkatkan Kesejahteraan Anggota Di Kampung Sumber Sari Kabupaten Kutai Barat. Jurnal Ilmu Pemerintahan, 3 (2).

Mahmud, Syamsuddin. (1986). Dasar-Dasar Ilmu Ekonomi dan Koperasi. Banda Aceh: PT Intermasa.

Safitri. (2016). Faktor-Faktor Pendorong dan Penghambat Kesuksesan Koperasi Mahasiswa Universitas Lampung. Skripsi Sarjana, Universitas Lampung Bandar Lampung.

Sugiyono. (2017). Metode Penelitian Bisnis. Bandung: Alfabeta.

Mutis, Thoby. (1992). Pengembangan Koperasi, Jakarta: Grasindo.

Sartika, Titik \& Soedjono, Abd. Rachman. (2002). Ekonomi Skala Kecil/Menengah dan Koperasi. Jakarta: Ghalia Indonesia Sari, Zulfa. (2010). Peran Koperasi Mahasiswa (KOPMA) Dalam Menumbuh Kembangkan Jiwa Kewirausahaan Pada Anggota Koperasi Di Universitas Islam Negeri Sultan Syarif Kasim Riau. Skripsi Sarjana, Universitas Negeri Sultan Syarif Kasim Riau Pekan Baru. 